ticularly in women and residents of the capital argues in favour of recent important changes in behavioural or environmental factors of importance to the development of this cancer. The contemporary changes in smoking habits and incidence of anal cancer would support the hypothesis that the anus is yet another site with increased susceptibility to carcinogens resulting from smoking. Recent changes in sexual habits also coincide with the trends in anal cancer incidence and suggest, as with cervical cancer, that an infectious agent is involved. Finally, men who had never married were found at increased risk since the 1940s, indicating a potential association with male homosexuality.

Support for this study was given by the Danish Cancer Society (grant No 90-7620). We are indebted to Dr HansOlov Adami, Cancer Epidemiology Unit, University Hospital, Uppsala, Sweden, and Dr Robert J Biggar, Environmental Epidemiology Branch, National Cancer Institute, Bethesda, USA, for their comments on the study's design and critical review of the manuscript.

1 Peters RK, Mack TM. Patterns of anal carcinoma by gender and marital status in Los Angeles county. Br f Cancer 1983;48:629-36.

2 Wexner SD, Milsom JW, Dailey TH. The demographics of anal cancer are changing. Dis Col Rect 1987;30:942-6.

3 Biggar RJ, Burnett W, Mikl J, Nasca P. Cancer among New York men at risk of acquired immunodeficiency syndrome. Int 9 Cancer 1989;43:979-98.

4 Austin DF. Etiological clues from descriptive epidemiology: squamous carcinoma of the rectum or anus. National Cancer Institute Monographs carcinoma of the

5 Daling JR, Weiss NS, Klopfenstein LL, Cochran LE, Chow WH, Daifuku R. Correlates of homosexual behaviour and the incidence of anal cancer. $¥ A M A$ 1982:247:1988-90.

6 Holly EA, Whittemore AS, Aston DA, Ahn DK, Nickoloff BJ, Kristiansen JJ Anal cancer incidence: genital warts, anal fissure or fistula, hemorrhoids, and smoking. $7 N C I 1989 ; 81: 726-3$

7 Holmes F, Borek D, Owen-Kummer M, Hassanein R, Fishback J, Behbehani A, et al. Anal cancer in women. Gastroenterology 1988;95:107-11.

8 Daling JR, Sherman KJ, Hislop TG, Maden C, Mandelson MT, Beckmann $\mathrm{AM}$, et al. Cigarette smoking and the risk of anogenital cancer. Am J Epidemiol 1992;135:180-9.

9 Daling JR, Weiss NS, Hislop TG, Maden C, Coates RJ, Sherman KJ, et al. Sexual practices, sexually transmitted diseases, and the incidence of anal cancer. N Engl f Med 1987;317:973-7.

10 Melbye M, Spregel P. Aetiological parallel between anal cancer and cervical cancer. Lancet 1991;338:657-9.

11 Zur Hausen $\mathrm{H}$. Papillomaviruses in anogenital cancer as a model to understand the role of viruses in human cancers. Cancer Res 1989;9:4677-81.

12 Penn I. Cancers of the anogenital region in renal transplant recipients. Cancer 1986;58:611-6.
13 Blohme I, Brynger H. Malignant disease in renal transplant patients. Transplantation 1985;39:23-5.

14 Hever D, Desmond S, Volberding P, Kahn J. Changing prevalence of malignancies in men at San Francisco General Hospital during the HIV epidemic. Fifth international conference on AIDS, Montreal, 1989. Ottawa: International Development Research Centre, 1989: abstract WBO19.

15 Beckmann AM, Daling JR, Sherman KJ, Maden C Miller BA, Bates RJ, et al. (Int $\mathcal{I}$ Cancer 1989;43: 1042-9.

16 Melbye M, Palefsky J, Gonzales J, Ryder LP, Nielsen H, Bergmann O, et al. Immune status as a determinant of human papillomavirus detection and its association with anal epithelial abnormalities. Int 7 Cancer 1990;46:203-6.

17 Caussy D, Goedert JJ, Palefsky J, et al. Interaction of human immunodeficiency virus and papillomaviruses: association with anal epithelial abnormality in

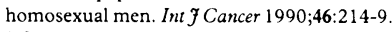

18 Palefsky JM, Gonzales J, Greenblatt RM, Ahn DK, Hollander H. Ana intraepithelial neoplasia and anal papillomavirus infection among homosexual males with group IV HIV disease. FAMA 1990;263:2911-6.

19 Storm HH. The Danish Cancer Registry, a self-reporting national cancer registration system with elements of active data collection. In: Jensen $\mathrm{OM}$ Parkin DM, Maclennan R, Muir CS, Skeet RG, eds. Cancer registration principles and methods. Lyons: International Agency for Research on Cancer, 1991:220-36. (IARC Scientific Publication No 95.)

20 Wagner G. History of cancer registration. In: Jensen OM, Parkin DM Maclennan R, Muir CS, Skeet RG, eds. Cancer registration, principles and methods. Lyons: International Agency for Research on Cancer, 1991:3-6. (IARC Scientific Publication No 95.)

21 Smith P. Comparison between registries: age-standardized rates. In: Muir C Waterhouse J, Mack T, Powel J, Whelan S, eds. Cancer incidence in five continents. Vol 5. Lyons: International Agency for Research on Cancer, 1987:790-5. (IARC Scientific Publications No 88.)

22 SAS Institute. SAS/STAT users guide, version 6 . Vol 2, 4th ed. Cary, NC: SA Institute, 1989:1325-1456

23 Goldman S, Glimelius B, Nilsson B, Påhlman L. Incidence of anal epidermoid carcinoma in Sweden 1970-1984. Acta Chir Scand 1989;155:191-7.

24 Rabkin CS, Biggar RJ, Melbye M, Curtis RE. Second primary cancers following anal and cervical carcinoma: evidence of shared etiologic factors. Am F Epidemiol 1992;136:54-8.

25 Daling JR, Sherman KJ. Relationship between human papillomavirus infection and tumours of anogenital sites other than the cervix. In: Munoz N, Bosch FX, Shah KV, Meheus A, eds. The epidemiology of cervical cancer and human papillomaviruses. Lyons: International Agency for Research on and human papillomaviruses. Lyons: International Agency

26 Melbye M, Biggar RJ. Interactions between persons at risk for AIDS and the general population in Denmark. Am f Epidemiol 1992;135:593-602.

27 Scholefield JH, Thornton Jones H, Cuzick J, Northover JMA. Anal cancer and marital status. Br f Cancer 1990;62:286-8.

28 Osler M. Smoking habits in Denmark from 1953 to 1991: a comparative analysis of results from three nationwide health surveys among adult Danes in 1953-54, 1986-87 and 1990-91. Int $f$ Epidemiol 1992;21:862-71.

29 Melbye M, Biggar RJ, Ebbesen P, Sarngadharan MG, Weiss SH, Gallo RC, et al. Seroepidemiology of HTLV-III antibody in Danish homosexual men: prevalence, transmission, and disease outcome. BMf 1984;289:573-5.

30 Palefsky JM, Holly EA, Gonzales J, Berline J, Ahn DK, Greenspan JS Detection of human papillomavirus DNA in anal intraepithelial neoplasia and anal cancer. Cancer Res 1991;51:1014-9.

(Accepted 26 November 1992$)$
MRC Environmental Epidemiology Unit Southampton General Hospital, Southampton SO9 4XY

D J P Barker, professor C Osmond, statistician S J Simmonds, research assistant

G A Wield, systems analyst

Correspondence to:

Professor Barker.

$B M 7$ 1993;306:422-6

\title{
The relation of small head circumference and thinness at birth to death from cardiovascular disease in adult life
}

\author{
D J P Barker, C Osmond, S J Simmonds, G A Wield
}

\begin{abstract}
Objective-To determine how fetal growth is related to death from cardiovascular disease in adult life.

Design-A follow up study of men born during 1907-24 whose birth weights, head circumferences, and other body measurements were recorded at birth.

Setting-Sheffield, England.

Subjects-1586 Men born in the Jessop Hospital.

Main outcome measure-Death from cardiovascular disease.

Results-Standardised mortality ratios for cardiovascular disease fell from 119 in men who weighed 5.5 pounds $(2495 \mathrm{~g})$ or less at birth to 74 in men who weighed more than 8.5 pounds $(3856 \mathrm{~g})$. The fall was significant for premature cardiovascular deaths up to 65 years of age $\left(\chi^{2}=5 \cdot 0, p=0 \cdot 02\right)$. Standardised mortality ratios also fell with increasing head circumference $\left(\chi^{2}=4.6, p=0.03\right)$ and increasing ponderal index (weight/length $\left.{ }^{3}\right)\left(\chi^{2}=3 \cdot 8, \mathbf{p}=0.05\right.$; for premature deaths $\left.\chi^{2}=6 \cdot 0, p=0 \cdot 01\right)$. They were not related to the duration of gestation. Among men for
\end{abstract}

whom the ratio of placental weight to birth weight was in the highest fifths the standardised mortality ratio wàs 137 .

Conclusion-These findings show that reduced fetal growth is followed by increased mortality from cardiovascular disease. They suggest that reduction in growth begins early in gestation. They are further evidence that cardiovascular disease originates through programming of the body's structure, physiology, and metabolism by the environment during fetal life. Maternal nutrition may have an important influence on programming.

\section{Introduction}

People who had low growth rates during fetal life and infancy have high death rates from ischaemic heart disease. Among 5654 men born in six districts of Hertfordshire, England, during 1911-30 death rates from ischaemic heart disease fell progressively between those with the lowest and highest weights at 1 year. The death rates in those who weighed 18 pounds $(8165 \mathrm{~g})$ or less at 1 year were almost three times greater 
than in those who weighed 27 pounds (12247 g) or more. ${ }^{1}$ Findings in women were similar (unpublished). Combined death rates from all causes other than cardiovascular disease did not vary with weight at 1 year. Death rates from cardiovascular disease fell with increasing birth weight but the relations were not as strong as with weight at 1 year.

Examination of men and women who still live in Hertfordshire has shown that lower birth weight and infant weight are associated with a higher incidence of known risk factors for cardiovascular disease, including raised blood pressure, ${ }^{2}$ plasma glucose and insulin concentrations, ${ }^{3}$ and plasma fibrinogen and factor VII concentrations. ${ }^{2}$ These associations parallel those with death rates from cardiovascular disease in that high early weight is associated with a low incidence of each risk factor. The associations are strong and graded and are independent of social class, either at birth or currently, and of influences in adult lifestyle such as smoking and alcohol consumption. A striking feature of the findings is that different risk factors are related to different patterns of early growth. Blood pressure is related to birth weight but not independently to weight at 1 year. Plasma fibrinogen concentrations are related to weight at 1 year but not independently to birth weight.

These findings are evidence that the pathogenesis of cardiovascular disease is programmed during the period of rapid growth in early life. ${ }^{4}$ The term programming is used for long term changes in the body's structure, physiology, or metabolism brought about by environmental influences acting at critical stages of early life. ${ }^{5}$ Animal experiments provide numerous examples of programming which occurs because the organs and systems of the body mature during periods of rapid growth before and immediately after birth. ${ }^{6-9}$ There are critical windows of time during which maturation must be achieved; failure of maturation is to some extent irrecoverable.

Birth weight, the only measurement recorded at birth in Hertfordshire, is a crude measure of fetal growth which summates head size, body length, and fatness. Blood pressure in children and adults is more strongly predicted by thinness at birth and a high ratio of placental weight to birth weight than by birth weight alone. ${ }^{10-12}$ Measurement of head size and length at birth gives an insight into the timing of growth retardation during intrauterine life. Furthermore, in the absence of data on duration of gestation, the consequences of retarded fetal growth cannot be distinguished from those of premature birth. We have therefore followed up a group of men born before 1925 in a hospital in Sheffield where routine measurements of the baby at birth included head circumference, body length, and duration of gestation.

\section{Subjects and methods}

From 1907 onwards a standardised record was kept for each woman admitted to the labour ward at the Jessop Hospital, Sheffield, England. The record contained details of the mother's previous pregnancies and external measurements of her pelvis, including the conjugate diameter (distance between the symphysis pubis and the fifth lumbar vertebra). The baby's birth weight, placental weight, length from crown to heel, head circumference, and biparietal and occipitofrontal diameters were also recorded. Up to 1922 weights were measured in pounds $(1 \mathrm{lb}=454 \mathrm{~g}: 1 \mathrm{lb}=16$ ounces); thereafter some were recorded in grams. Lengths, head circumferences and diameters were measured in inches $(1$ inch $=2.54 \mathrm{~cm})$. Measurements were often rounded, and we therefore preserved the units as pounds and inches and converted weights in grams to pounds. In $91 \%$ of the records the mother's conjugate diameter was measured in centimetres: we preserved these units.

Most girls born 70 and more years ago cannot be traced because of change of name at marriage. We therefore studied only boys. A total of 2421 singleton boys were born alive during 1907-24 and had their birth weight and either head circumference or both head diameters recorded. Overall $1586(66 \%)$ were traced through the NHS central registry at Southport, and 693 had died between 1 January 1951 and 31 December 1990 . The average birth weight of men who were not traced was 0.2 pounds $(91 \mathrm{~g})$ less than those who were traced.

We analysed cause of death in relation to measurements at birth. The numbers of deaths were compared with those expected from national rates for men of corresponding age and year of birth. ${ }^{13}$ Death rates were expressed as standardised mortality ratios, with the national average as 100 . Cardiovascular disease was defined by ICD (ninth revision) codes 390-459. The social class for all except 27 of the men who died could be derived from the occupation recorded on the death certificate.

Head circumference had not been recorded for 137 men, but this could be estimated from the two head diameters by using the regression equation derived from the 1042 records which included the circumference and both diameters.

\section{Results}

A total of 316 of the deaths in the 1586 men were due to cardiovascular disease, 235 being certified as due to ischaemic heart disease, 49 to stroke, and 32 to other circulatory diseases. The overall death rate from cardiovascular disease was close to the national average, the standardised mortality ratio being 94 .

The average birth weight of the men was $7 \cdot 3$ pounds $(3311 \mathrm{~g})$. Table I shows that standardised mortality ratios from cardiovascular disease fell with increasing birth weight $\left(x^{2}=3.5, p=0.06\right)$. There was no similar trend for other causes of death. Table I also shows the trends in deaths at ages up to 65 years. The fall with increasing birth weight was significant $\left(x^{2}=5 \cdot 0\right.$, $\mathrm{p}=0.02)$.

The average head circumference at birth was 13.9 inches $(35.3 \mathrm{~cm})$. Standardised mortality ratios from cardiovascular disease fell with increasing head

TABLE I-Standardised mortality ratios according to weight, head circumference, and ponderal index at birth. Numbers of deaths in parentheses

\begin{tabular}{|c|c|c|c|c|}
\hline \multirow{3}{*}{$\begin{array}{l}\text { Variable } \\
\text { measured }\end{array}$} & \multicolumn{4}{|c|}{ Cause of death } \\
\hline & \multicolumn{2}{|c|}{ Cardiovascular disease } & \multirow{2}{*}{$\begin{array}{l}\text { Other } \\
\text { causes }\end{array}$} & \multirow{2}{*}{$\begin{array}{c}\text { All } \\
\text { causes }\end{array}$} \\
\hline & All ages & $<65$ years & & \\
\hline \multicolumn{5}{|c|}{ Birth weight (pounds) ${ }^{\star}$} \\
\hline $\begin{array}{r}\leqslant 5.5 \\
-6.5 \\
-7.5 \\
-8.5 \\
>8.5\end{array}$ & $\begin{array}{c}119(21) \\
95(61) \\
105(134) \\
82(73) \\
74(27)\end{array}$ & $\begin{array}{r}125(13) \\
101(34) \\
111(77) \\
71(36) \\
68(14)\end{array}$ & $\begin{array}{c}118(22) \\
99(67) \\
101(136) \\
110(103) \\
127(49)\end{array}$ & $\begin{array}{r}118(43) \\
97(128) \\
103(270) \\
97(176) \\
101(76)\end{array}$ \\
\hline${ }_{\text {Head circu }}^{\text {All }}$ & $\begin{array}{l}94(316) \\
\text { ches) } t\end{array}$ & $94(174)$ & $107(377)$ & $101(693)$ \\
\hline $\begin{array}{r}\leqslant 13 \\
<14 \\
14 \\
>14\end{array}$ & $\begin{array}{r}114(65) \\
105(98) \\
81(95) \\
86(58)\end{array}$ & $\begin{array}{r}119(40) \\
97(48) \\
86(55) \\
81(31)\end{array}$ & $\begin{array}{c}95(57) \\
99(97) \\
113(139) \\
118(84)\end{array}$ & $\begin{array}{r}104(122) \\
102(195) \\
97(234) \\
102(142)\end{array}$ \\
\hline $\begin{array}{c}\text { All } \\
\text { Ponderal ir }\end{array}$ & $\begin{array}{c}94(316) \\
\text { s/inches }{ }^{3} \times 10\end{array}$ & $\underset{00) \ddagger}{94(174)}$ & $107(377)$ & $101(693)$ \\
\hline $\begin{array}{r}\leqslant 12.5 \\
-13.8 \\
-15.1 \\
>15.1\end{array}$ & $\begin{array}{c}113(83) \\
97(78) \\
86(67) \\
85(66)\end{array}$ & $\begin{array}{r}118(48) \\
103(45) \\
89(39) \\
69(29)\end{array}$ & $\begin{array}{l}105(81) \\
108(91) \\
110(91) \\
106(87)\end{array}$ & $\begin{array}{r}109(164) \\
103(169) \\
98(158) \\
95(153)\end{array}$ \\
\hline All & $95(294)$ & $95(161)$ & $107(350)$ & $101(644)$ \\
\hline
\end{tabular}

$\star$ Birth weights given in pounds because of original data; 1 pound $=454 \mathrm{~g}$. tHead circumference given in inches because of original data; 1 inch= $2.54 \mathrm{~cm}$. $\$ 16$ Ounces $=1$ pound. 
circumference $\left(\chi^{2}=4 \cdot 6, p=0 \cdot 03\right)$ (table I). Deaths from other causes, however, showed an opposite trend $\left(\chi^{2}=2 \cdot 6, p=0 \cdot 11\right)$; men with the largest head circumferences having the highest standardised mortality ratios. The trend with head circumference was apparent for deaths before 65 years, though not significant $\left(\chi^{2}=3 \cdot 1, p=0 \cdot 08\right)$.

Crown-heel length at birth was recorded for 1454 men. The average was 20.3 inches $(51.6 \mathrm{~cm})$. There were no trends in death from cardiovascular or noncardiovascular disease with length, though men whose length at birth was 20 inches $(50.8 \mathrm{~cm})$ or less had a standardised mortality ratio of 103 from cardiovascular disease, compared with 93 in the remainder.

We calculated the ponderal index at birth as birth weight (ounces)/length (inches) ${ }^{3}$. Table I shows that standardised mortality ratios from cardiovascular disease fell with increasing ponderal index $\left(\chi^{2}=3 \cdot 8, p=\right.$ $0 \cdot 05)$. There was no similar trend for other causes of death. Deaths from all causes combined also fell with increasing ponderal index. The trend with ponderal index was apparent for deaths before 65 years and was significant $\left(X^{2}=6 \cdot 0, p=0 \cdot 01\right)$.

When the data were divided according to head circumference and ponderal index (table II) the highest standardised mortality ratio for cardiovascular disease (119) was in men who had both small head circumference and low ponderal index at birth. Conversely the lowest mortality ratio (80) was in those with a large head circumference and high ponderal index. The corresponding figures for deaths before 65 years were 120 and 75 .

TABLE II-Standardised mortality ratios for cardiovascular disease according to head circumference and ponderal index at birth. Numbers of deaths in parentheses

\begin{tabular}{lccr}
\hline \multirow{2}{*}{$\begin{array}{l}\text { Head circumference } \\
\text { (inches) }\end{array}$} & \multicolumn{3}{c}{ Ponderal index (ounces/inches'× 1000) $\dagger$} \\
\cline { 2 - 4 } & $\leqslant 13 \cdot 8$ & $>13.8$ & \multicolumn{1}{c}{ All } \\
\hline$<14$ & $119(92)$ & $94(57)$ & $108(149)$ \\
$\geqslant 14$ & $91(69)$ & $80(76)$ & $85(145)$ \\
All & $105(161)$ & $85(133)$ & $95(294)$ \\
\hline
\end{tabular}

$\star 1 \mathrm{Inch}=2.54 \mathrm{~cm} . \quad+16$ Ounces $=1$ pound, 1 pound $=454 \mathrm{~g}$.

III-Standardised mortality ratios according to ratio of placental weight to birth weight and duration of gestation. Numbers of deaths in parentheses

\begin{tabular}{|c|c|c|c|c|}
\hline \multirow{3}{*}{$\begin{array}{l}\text { Variable } \\
\text { measured }\end{array}$} & \multicolumn{4}{|c|}{ Cause of death } \\
\hline & \multicolumn{2}{|c|}{ Cardiovascular disease } & \multirow{2}{*}{$\begin{array}{l}\text { Other } \\
\text { causes }\end{array}$} & \multirow{2}{*}{$\begin{array}{c}\text { All } \\
\text { causes }\end{array}$} \\
\hline & All ages & $<65$ years & & \\
\hline \multicolumn{5}{|c|}{ Placental weight/birth weight $\times 100$} \\
\hline$\leqslant 15$ & $93(45)$ & $89(25)$ & $90(46)$ & $91(91)$ \\
\hline $17 \cdot 5$ & $89(60)$ & $90(35)$ & $119(84)$ & $105(144)$ \\
\hline $19 \cdot 0$ & $80(38)$ & $61(16)$ & $138(69)$ & $110(107)$ \\
\hline $21 \cdot 5$ & $87(54)$ & $77(25)$ & $105(69)$ & $96(123)$ \\
\hline$>21.5$ & $137(74)$ & $146(41)$ & $107(61)$ & $122(135)$ \\
\hline All & $97(271)$ & $92(142)$ & $112(329)$ & $105(600)$ \\
\hline \multicolumn{5}{|c|}{ Duration of gestation (weeks) } \\
\hline$\leqslant 37$ & $107(26)$ & $77(11)$ & $78(20)$ & $92(46)$ \\
\hline 38 & $85(15)$ & $97(10)$ & $119(22)$ & $102(37)$ \\
\hline 39 & $91(30)$ & $87(17)$ & $87(30)$ & $89(60)$ \\
\hline 40 & $95(39)$ & $91(22)$ & $92(40)$ & $94(79)$ \\
\hline 41 & $92(23)$ & $99(15)$ & $125(33)$ & $109(56)$ \\
\hline$>41$ & $89(19)$ & $92(12)$ & $146(33)$ & $119(52)$ \\
\hline All & $94(152)$ & $90(87)$ & $104(178)$ & $99(330)$ \\
\hline
\end{tabular}

TABLE IV-Mean birth weight, head circumference, and ponderal index according to social class at death

\begin{tabular}{|c|c|c|c|c|}
\hline \multirow[b]{2}{*}{ Mean } & \multicolumn{4}{|c|}{ Social class } \\
\hline & $\begin{array}{c}\text { I, II, III } \\
\text { Non-manual } \\
\text { (134 deaths) }\end{array}$ & $\begin{array}{l}\text { III Manual } \\
\text { (266 deaths) }\end{array}$ & $\begin{array}{c}\text { IV, V } \\
\text { (266 deaths) }\end{array}$ & All (SD) \\
\hline Birth weight (pounds) ${ }^{\star}$ & $7 \cdot 4$ & $7 \cdot 3$ & $7 \cdot 2$ & $7 \cdot 3(1 \cdot 1)$ \\
\hline Head circumference (inches) $\dagger$ & $13 \cdot 9$ & 13.9 & $13 \cdot 8$ & $13.9(0.7)$ \\
\hline Ponderal index (ounces $/$ inches $\left.^{3} \times 1000\right) \ddagger$ & $13 \cdot 9$ & $14 \cdot 0$ & $13 \cdot 8$ & $13.9(2.0)$ \\
\hline
\end{tabular}

$\star$ One pound $=454 \mathrm{~g}$.

†One inch $=2.54 \mathrm{~cm}$.
Placental weight was recorded for 1320 men. The average was 1.3 pounds $(590 \mathrm{~g})$. Standardised mortality ratios from cardiovascular disease showed no trend with placental weight. The highest standardised mortality ratio (119), however, was in men for whom the placental weights were above 1.25 pounds $(567 \mathrm{~g})$ and who had a birth weight of 6.5 pounds $(2948 \mathrm{~g})$ or less. Table III shows standardised mortality ratios according to the ratio of placental weight to birth weight. The highest standardised mortality ratio for cardiovascular disease $(137,95 \%$ confidence interval 108 to 172) was in men with the highest placental weight/birth weight ratio. These men also had the highest standardised mortality ratio for all causes of death. The comparable figure for deaths before 65 years was 146 (105 to 198). In the same way as in previous analyses we divided the men according to whether or not the placental weight was above 1.25 pounds $(567 \mathrm{~g}){ }^{11}$ Among men in the high placental weight group there was a significant trend of increasing standardised mortality ratios for cardiovascular disease with increasing placental weight to birth weight ratio.

Length of gestation was recorded for 822 men. Table III shows that standardised mortality ratios for cardiovascular disease were not related to duration of gestation, though the highest ratio, 107, was in men born at 37 weeks or less. Standardised mortality ratios for other causes of death were higher in babies born after 40 weeks, being 135 (104 to 172) compared with 92 (75 to 110 ) in men born at or before term. Of the 66 deaths from other causes in men born after term, 34 were from malignant neoplasms. Fifty of the deaths were in men whose head circumference at birth was 14 inches $(35.6 \mathrm{~cm})$ or more. The standardised mortality ratio in these men was 159 (118 to 209) compared with 91 (52 to 148) in the other men born after term.

The number of previous pregnancies was recorded for all except 23 of the mothers; $33 \%$ were primiparous. There were no trends in standardised mortality ratios from cardiovascular disease or other causes with the number of previous pregnancies.

The external conjugate diameter of the pelvis of 1096 mothers was recorded. The mean was $18.7 \mathrm{~cm}$. Standardised mortality ratios from cardiovascular disease fell from 116 to 91 as the external conjugate diameter increased from $17 \mathrm{~cm}$ or less to $20 \mathrm{~cm}$ and over. The babies' head circumferences correlated strongly with the external conjugate diameters, increasing by 0.17 inches $(0.10$ to 0.24$)$ for each centimetre increase in external conjugate diameter. The trend in cardiovascular mortality with external conjugate was abolished by allowing for head circumference. In contrast the trend in cardiovascular mortality with head circumference (table I) remained significant after allowing for external conjugate diameter.

Among the men who died mean birth weight, head circumference, and ponderal index were lowest in those in social classes IV and V (table IV), though the differences were not significant.

\section{Discussion}

We traced a group of men born in a maternity hospital in Sheffield before 1925 and related size at birth to subsequent death rates from cardiovascular disease. Cardiovascular death rates fell progressively with increasing birth weight. The fall was significant for deaths before the age of 65 years. We found a similar trend in a previous study in Hertfordshire, ${ }^{1}$ the only other study in which a group of people has been traced from birth to death. In Hertfordshire weight was the only measurement recorded at birth. The Sheffield records were unusually detailed. The study shows that men who had a small head circumference or 
were thin at birth, or both, had higher rates of cardiovascular death than those who had a large head circumference or were fat.

Cardiovascular mortality was not related to the duration of gestation except for a small increase in death rates in men born prematurely. The associations with head circumference and thinness must therefore reflect reduced fetal growth. This is consistent with studies of cardiovascular risk factors in men and women aged 50 years in Preston. Birth measurements including weight, head circumference, length, and placental weight predicted blood pressure ${ }^{1112}$ and plasma glucose, insulin, ${ }^{14}$ and fibrinogen concentrations $s^{2}$ independently of duration of gestation.

Our study population comprised men born in one maternity hospital during $1907-24$. We traced $66 \%$ of the singleton boys initially included in the study. Those who were not traced differed slightly from those who were: their birth weight was 0.2 pounds $(91 \mathrm{~g}$ ) less, for example. Many of them must have died in infancy and childhood, but we have no data on deaths before 1951 . The standardised mortality ratio from all causes of death was 101 in the study population, similar to that of 104 for the whole population of Sheffield during 1968-78. ${ }^{15}$ Our analysis was based on internal comparisons, and selection bias would be introduced only if the relation of head circumference and ponderal index to death from cardiovascular disease differed in those who were or were not traced. This is unlikely.

We have information on social class only for men who died. Those in social class IV and V had lower birth weight, head circumference, and ponderal index. The differences, however, were small. We do not think that reduced fetal growth is associated with death from cardiovascular disease merely through an association with adverse influences acting in the adult lives of people of low social class. This conclusion is strongly supported by our studies of men and women in Hertfordshire and Preston in which reduced fetal growth was associated with high blood pressure, impaired glucose tolerance, and raised plasma fibrinogen and factor VII concentrations in each social class and at each level of cigarette smoking, alcohol consumption, and obesity. ${ }^{2312} 14$

The studies in Preston have shown that babies who have low birth weight in relation to duration of gestation, who have small head circumference, and are thin at birth tend as adults to develop high blood pressure, ${ }^{11}$ impaired glucose tolerance, and syndrome $\mathrm{X}^{16}$ - a combination of hypertension, non-insulin dependent diabetes, disordered lipids, hyperinsulinaemia, obesity, and abdominal fatness. This pattern of impaired fetal growth has now been shown to be linked to cardiovascular disease. Thinness at birth is a particularly strong predictor of death before 65 years of age. In addition, men in Sheffield who were short at birth, with a birth length of 20 inches $(50.8 \mathrm{~cm})$ or less, also had higher cardiovascular death rates, though the difference was small. In the Preston studies shortness at birth was associated with hypertension and raised plasma fibrinogen concentrations in adult life. ${ }^{211}$

The differences in cardiovascular mortality associated with head circumference and thinness at birth are not as large as those associated with weight at 1 year. In Hertfordshire there were threefold differences in death rates from ischaemic heart disease between men with the lowest and highest weights at 1 . We think there may be at least two explanations for this. Firstly, programming of cardiovascular disease may continue during infancy. Plasma fibrinogen concentrations, for example, are related to weight at 1 year but not independently to birth weight. Plasma lipid concentrations and death rates from ischaemic heart disease vary according to the method of infant feeding. ${ }^{17}$ Secondly, the range of birth weights is less than the range of infant weights, and head circumference and length at birth are known to be inaccurate measurements. The strength of associations with birth measurements may therefore be reduced. Furthermore, body measurements at birth are only proxies for variables more closely related to the processes that underlie programming.

Data on cardiovascular disease from death certificates are known to be inaccurate. Consistent with this, birth weight is more strongly associated with death before 65 years than with death at all ages. Studies of cardiovascular risk factors show much larger trends than those with cardiovascular deaths. ${ }^{4}$ The relative risk of impaired glucose tolerance and diabetes, for example, was six times higher in men with birth weights of 5.5 pounds $(2495 \mathrm{~g})$ or less compared with those with birth weights of more than 9.5 pounds $(4309 \mathrm{~g}){ }^{3}$

We suggest that small head circumference and thinness at birth reflect patterns of fetal growth associated with changes in certain tissues, including blood vessels and the endocrine pancreas. These changes programme blood pressure, glucose and insulin metabolism, and cardiovascular disease in adult life. The nature of the changes, which could include modification of gene expression, permanent reduction in cell numbers, or modification of organ structure, is unknown. This study does, however, give an insight into the influences which reduce fetal growth and their timing in gestation.

Cardiovascular death rates were high in men with a high ratio of placental weight to birth weight. In the Preston studies men and women who had had a high ratio of placental weight to birth weight had raised blood pressure, ${ }^{12}$ higher rates of impaired glucose tolerance, ${ }^{14}$ and raised plasma fibrinogen concentrations. ${ }^{2}$ Disproportionately large placental size may be a consequence of maternal undernutrition. It occurs in babies whose mothers were anaemic during pregnancy. ${ }^{18} 19$ It can be produced in sheep by reducing the food intake of ewes in early pregnancy. ${ }^{202}$ We suggest that maternal undernutrition, by constraining fetal growth, may programme cardiovascular disease.

Fetal growth is actively constrained by maternal size. ${ }^{22}$ In this study the external conjugate diameter of the mother's pelvis was strongly related to the baby's size, including head circumference. The external conjugate was not, however, related to cardiovascular mortality after adjusting for head circumference whereas the trend in cardiovascular mortality with head circumference remained significant after allowing for the external conjugate diameter. In Preston, mothers' external conjugate diameters were similarly unrelated to blood pressure after allowing for birth weight and placental weight." mechanisms which constrain fetal growth to prevent maternal-fetal disproportion do not effect long term programming of cardiovascular disease.

A recent study showed that babies born with smaller head circumferences and lower ponderal indices had a higher fetal heart rate at 18 weeks. ${ }^{23}$ This was only partly explained by earlier births of babies with higher heart rates. The faster heart rates may therefore have resulted from the babies already being small in midgestation.

Our findings reveal for the first time death rates of babies born before term who survive into late adult life, although duration of gestation was recorded for only half of the men. Among those born before 38 weeks death rates from cardiovascular disease were a little higher but death rates from all causes were around average. This may give limited reassurance that the increasing numbers of preterm babies kept alive in neonatal units will not have greatly increased death rates as adults. By contrast babies born after 40 
weeks' gestation had raised death rates from noncardiovascular causes, reflected in higher rates from all causes combined. This was unexpected and requires confirmation by continued follow up and other studies now in progress. The babies born after term had larger head size, which was also associated with higher rates of disease other than cardiovascular disease.

In conclusion, this study shows for the first time that reduced fetal growth is followed by higher death rates from cardiovascular disease in adult life. Bodily proportions at birth suggest that the growth reduction began early in gestation. We suggest that this is further evidence that cardiovascular disease originates through programming in fetal life and infancy. Maternal nutrition may be an important influence on programming.

We are grateful to Mr D R Millar, consultant obstetrician; Mrs Bullas and the staff of the medical records department at the Jessop Hospital for Women who preserved the records and allowed us to use them; and to the staff at NHS central registry and OPCS who traced the men. The study was supported by a grant from the Wellcome Trust.

1 Barker DJP, Winter PD, Osmond C, Margetts B, Simmonds SJ. Weight in infancy and death from ischaemic heart disease. Lancet 1989;ii:577-80.

2 Barker DJP, Meade TW, Fall CHD, Lee A, Osmond C, Phipps K. The relation of fetal and infant growth to plasma fibrinogen and factor VII in adult life. BMF 1992;304:148-52.

3 Hales CN, Barker DJP, Clark PMS, Cox LJ, Fall C, Osmond C, et al. Fetal and infant growth and impaired glucose tolerance at age 64. BMY 1991;303:1019-22.

4 Barker DJP, ed. Fetal and infant origins of adult disease. London: British Medical Journal, 1992.

5 Lucas A. Programming by early nutrition in man. In: Bock GR, Whelan J, eds. The childhood environment and adult disease. Ciba Foundation Symposium 156. Chichester: John Wiley, 1991:38-50.
6 Dubos R, Savage D, Schaedler R. Biological Freudianism: lasting effects of early environmental influences. Pediatrics 1966;38:789-800.

7 Winick $M$, Noble $A$. Cellular response in rats during malnutrition at various ages. F Nutr 1966;89:300-6

8 Blackwell NM, Blackwell RQ, Yu TTS, Weng YS, Chow BF. Further studies on growth and feed utilization in progeny of underfed mother rats. I Nutr 1968;97:79-84.

9 Hahn P. Effect of litter size on plasma cholesterol and insulin and some liver and adipose tissue enzymes in adult rodents. I Nutr 1984;114:1231.

10 Law CM, Barker DJP, Bull AR, Osmond C. Maternal and fetal influences on blood pressure. Arch Dis Child 1991;66:1291-5.

11 Barker DJP, Godfrey KM, Osmond C, Bull A. The relation of fetal length, ponderal index, and head circumference to blood pressure and the risk of hypertension in adult life. Paediatr Perinat Epidemiol 1992;6:35-44.

12 Barker DJP, Bull AR, Osmond C, Simmonds SJ. Fetal and placental size and risk of hypertension in adult life. $B M \mathcal{F}$ 1990;301:259-62.

13 Berry G. The analysis of mortality by the subject-years method. Biometric 1983;39:173-84.

14 Phipps K, Barker DJP, Hales CN, Fall CHD, Osmond C, Clark PMS. Fetal growth and impaired glucose tolerance in men and women. Diabetologia 1993. (In press.)

15 Gardner MJ, Winter PD, Barker DJP. Atlas of mortality from selected diseases in England and Wales, 1968-78. Chichester: Wiley, 1984.

16 Barker DJP, Hales CN, Fall CHD, Osmond C, Phipps K, Clark PMS. Noninsulin dependent diabetes, hypertension and hyperlipidaemia (syndrome $\mathrm{X}$ ): relation to reduced fetal growth. Diabetologia 1993;36:62-7.

17 Fall CHD, Barker DJP, Osmond C, Winter PD, Clark PMS, Hales CN. Relation of infant feeding to adult serum cholesterol concentration and death Relation of infant feeding to adult serum cholesterol
from ischaemic heart disease. $B M{ }^{\mathcal{O}} 1992 ; 304: 801-5$.

18 Beischer MA, Sivasamboo R, Vohra S, Silpisom Rosal S, Reid S. Placental hypertrophy in severe pregnancy anaemia. $f$ Obstet Gynaecol, Br Comm 1970;77:398-409.

19 Godfrey KM, Redman CWG, Barker DJP, Osmond C. The effect of maternal anaemia and iron deficiency on the ratio of fetal weight to placental weight. Br F Obstet Gynaecol 1991;98:886-91.

20 Farchney GJ, White GA. Effects of maternal nutritional status on fetal and placental growth and on fetal urea synthesis. Austr f Biol Sci 1987;40: 365-77.

21 McCrabb GJ, Egan AR, Hosking BJ. Matemal undernutrition during midpregnancy in sheep. Placental size and its relationship to calcium transfer during la in shep. Pr Nutr 1991:65:157-68.

22 Butler N, Alberman ED. Second report of the 1958 British perinatal morality survey. Edinburgh and London: Livingstone, 1969.

23 Robinson SM, Wheeler T, Hayes MC, Barker DJP, Osmond C. Fetal heart rate and intrauterine growth. BrF Obstet Gynaecol 1991;98:1223-7.

(Accepted 1 December 1992)

\title{
Sexually transmitted diseases and HIV-1 infection among homosexual men in England and Wales
}

\author{
B G Evans, M A Catchpole, J Heptonstall, J Y Mortimer, C A McCarrigle, A G Nicoll, P Waight, \\ O N Gill, A V Swan
}

Public Health Laboratory

Service AIDS Centre,

Communicable Disease

Surveillance Centre,

London NW9 5EO

B G Evans, consultant

epidemiologist

M A Catchpole, consultant

epidemiologist

JY Mortimer, principal

scientist

C A McGarrigle, senior

scientist

A G Nicoll, consultant

epidemiologist

O N Gill, consultant

epidemiologist

Public Health Laboratory

Service, Communicable

Disease Surveillance

Centre (Immunisation

Division)

J Heptonstall, consultant

microbiologist

P Waight, principal scientist

Public Health Laboratory Service, Statistics Unit

A V Swan, head

Correspondence to:

Dr Evans.

BMF 1993;306:426-8

\section{Abstract}

Objective-To examine surveillance data for evidence of changing sexual behaviour and continuing transmission of HIV-1 among men who have sex with men.

Design-Analytic study of surveillance data on sexually transmitted diseases.

Setting-England and Wales.

Main outcome measures-Number of cases of rectal gonorrhoea and newly diagnosed HIV infection in homosexual men.

Results-New cases of gonorrhoea among men attending genitourinary medicine clinics increased by $7 \cdot 7 \%$ in 1989 and by $4 \cdot 2 \%$ in 1990 . Reports of rectal isolates of Neisseria gonorrhoeae also rose and the male to female ratio for patients with rectal gonorrhoea changed from 0.3:1 during 1988-9 to 2.6:1 in 1990-1. Although the overall number of cases of acute hepatitis $B$ fell during 1988-91, 81 and 82 homosexual men were infected in 1990 and 1991 respectively compared with 50 and 42 in 1988 and 1989. 1526 men had HIV-1 infection diagnosed in 1991, the largest number since 1987. Twenty eight of the $97(29 \%)$ men who seroconverted between January 1989 and December 1991 were aged less than 25 . The proportion of men aged 15-19 who were found to be infected with HIV-1 at their first test increased from an average of $2 \cdot 4 \%$ up to 1990 to $4.7 \%$ in the first nine months of 1991 . The prevalence of HIV infection in men under 25 attending genitourinary medicine clinics in London was $17 \%$ compared with $7 \cdot 8 \%$ outside London.

Conclusion-Unsafe sexual behaviour and HIV transmissions have increased among homosexual men after a period of decline. Recent HIV transmissions may disproportionately affect younger men.

\section{Introduction}

A decline in the incidence of sexually transmitted diseases in men who have sex with men was well documented in the mid-1980s in various developed countries, including the Netherlands, ${ }^{1}$ the United States, ${ }^{2}$ and Britain. ${ }^{3}$ Those undertaking health promotion saw this as evidence that sexual behaviour could be changed and that educational messages about safer sex had been heeded by homosexual men. In Britain, however, homosexual men infected with HIV-1 still contracted gonorrhoea, ${ }^{4}$ which implied continued participation in unprotected sexual intercourse. In 1989 increases in the incidence of sexually transmitted disease in homosexual men in the United States suggested that high risk sexual behaviour between men was increasing after a period of decline. Increases in sexually transmitted diseases in homosexual men were also reported in Amsterdam ${ }^{6}$ and Australia. $^{7}$

In 1990 increases in rectal gonorrhoea in men were noted in several genitourinary medicine clinics in London and elsewhere in Britain. ${ }^{8-13}$ Repeat testing 